Board of Governors of the Federal Reserve System

International Finance Discussion Papers

Number 1008

September 2010

\title{
Entry Dynamics and the Decline in Exchange-Rate Pass-Through
}

Christopher Gust, Sylvain Leduc, and Robert J. Vigfusson

NOTE: International Finance Discussion Papers are preliminary materials circulated to stimulate discussion and critical comment. References in publications to International Finance Discussion Papers (other than an acknowledgment that the writer has had access to unpublished material) should be cleared with the author or authors. Recent IFDPs are available on the Web at www.federalreserve.gov/pubs/ifdp/. This paper can be downloaded without charge from Social Science Research Network electronic library at http://www.ssrn.com/. 


\title{
Entry Dynamics and the Decline in Exchange-Rate Pass-Through*
}

\author{
Christopher Gust ${ }^{\dagger}$ Sylvain Leduc $\ddagger$ and Robert J. Vigfusson ${ }^{\S}$
}

\begin{abstract}
The degree of exchange-rate pass-through to import prices is low. An average passthrough estimate for the 1980s would be roughly 50 percent for the United States implying that, following a 10 percent depreciation of the dollar, a foreign exporter selling to the U.S. market would raise its price in the United States by 5 percent. Moreover, substantial evidence indicates that the degree of pass-through has since declined to about 30 percent.

Gust, Leduc, and Vigfusson (2010) demonstrate that, in the presence of pricing complementarity, trade integration spurred by lower costs for importers can account for a significant portion of the decline in pass-through. In our framework, pass-through declines solely because of markup adjustments along the intensive margin.

In this paper, we model how the entry and exit decisions of exporting firms affect passthrough. This is particularly important since the decline in pass-through has occurred as a greater concentration of foreign firms are exporting to the United States.

We find that the effect of entry on pass-through is quantitatively small and is more than offset by the adjustment of markups that arise only along the intensive margin. Even though entry has a relatively small impact on pass-through, it nevertheless plays an important role in accounting for the secular rise in imports relative to GDP. In particular, our model suggests that over $3 / 4$ of the rise in the U.S. import share since the early $1980 \mathrm{~s}$ is due to trade in new goods

Thus, a key insight of this paper is that adjustment of markups that occur along the intensive margin are quantitatively more important in accounting for secular changes in pass-through than adjustments that occur along the extensive margin.
\end{abstract}

JEL Classification: F15, F41

Keywords: Pass-through, trade integration, strategic complementarity, intensive margin.

${ }^{*}$ The views expressed in this paper are solely the responsibility of the authors and should not be interpreted as reflecting the views of the Board of Governors of the Federal Reserve System, the Federal Reserve Bank of San Francisco or of any other person associated with the Federal Reserve System.

${ }^{\dagger}$ Federal Reserve Board. Email: christopher.gust@frb.gov.

${ }^{\ddagger}$ Federal Reserve Bank of San Francisco. Email: sylvain.leduc@sf.frb.org.

${ }^{\S}$ Federal Reserve Board. Email: robert.vigfusson@frb.gov. 


\section{Introduction}

It is well known that the degree of exchange-rate pass-through (pass-through herein) to import prices is low. The evidence surveyed in Goldberg and Knetter (1997) suggest that an average pass-through estimate for the 1980s would be roughly 50 percent for the United States, implying that, following a 10 percent depreciation of the dollar, a foreign exporter selling to the U.S. market would raise its price in the United States by 5 percent. Moreover, there is substantial evidence that the degree of pass-through to U.S. import prices has declined considerably since the early 1990s, to a level of about 30 percent.

In Gust, Leduc, and Vigfusson (2010), we attempt to explain these findings by demonstrating that, in the presence of pricing complementarity, trade integration spurred by lower tariffs, transport costs, and changes in relative productivities accounts for a significant portion of the decline in pass-through. In our framework, trade integration reduces pass-though because pricing complementarity induces an exporter to set a relatively high and variable markup when its costs are lower than its competitors and a low and unresponsive markup when its costs are relatively high. Pass-through thus declines solely because of markup adjustments along the intensive margin, as we abstracted from the entry and exit decisions of exporting firms.

In this paper, we instead examine how entry dynamics affect pass-through in the presence of declines in trade costs and changes in relative productivities across countries that help account for greater U.S. openness. This is particularly important since the decline in pass-through has occurred at a time when the U.S. economy has become increasingly open with a greater concentration of foreign firms exporting to the United States. Dornbusch (1987), for instance, shows that an increasing presence of foreign firms should reduce firms' pricing power in U.S. markets, result in less variable markups, and therefore put upward pressure on pass-through to import prices.

Once we extend our model to incorporate such a mechanism, we find that the effect of entry on pass-through is quantitatively small and is more than offset by the adjustment of markups that arise only along the intensive margin. Even though entry has a relatively small impact on pass-through, it nevertheless plays an important role in accounting for the secular 
rise in imports relative to GDP. In particular, our model suggests that over $3 / 4$ of the rise in the U.S. import share since the early 1980s is due to trade in new goods. To have a more significant impact on pass-through, firms' entry in our framework would need to generate a much larger increase in the share of imports than is observed empirically. Thus, a key insight of this paper is that adjustment of markups that occur along the intensive margin are quantitatively more important in accounting for secular changes in pass-through than adjustments that occur along the extensive margin.

The paper is organized as follows. The next section presents evidence on the decline in pass-through in the United States, while Section 3 describes the time-series properties of trade costs and documents changes in productivities in different regions of the world. The model is described in Section 4, and we relate our statistical measure of pass-through to the model in Section 5. Section 6 discusses the model's calibration and our results are presented in Section 7. The last section concludes.

\section{U.S. Import Prices and the Real Exchange Rate}

We first examine the statistical relationship between import prices and the exchange rate and document the increasing disconnect between these variables. Our analysis closely follows Gust, Leduc, and Vigfusson (2010), who provide a more detailed treatment of this relationship.

In our analysis, we focus on imports that are included in the end-use categories of automotive products, consumer goods, and capital goods, excluding computers and semiconductors. We will refer to these categories as finished goods, which account for 45 percent of the nominal value of total imports since 1987.

We concentrate on this more narrowly defined measure of import prices for two reasons. First, we exclude import prices of services, computers, and semiconductors because of concerns about price measurement. Second, our preferred measure excludes import prices of foods, feeds, beverages, and industrial supplies, because we view our model as less applicable to these categories. In particular, we model the determination of import prices as arising from the 
decisions of firms that are monopolistic competitors and have the ability to price discriminate across countries. In the context of our model, excluding these goods is sensible since for many of these goods the extent of monopolistic behavior and price discrimination is limited.

We argue that the decline in pass-through can be understood using a real model and thus focus on real import prices and real exchange rates. Accordingly, we define the real price of imports as the ratio of the finished goods import price deflator to the U.S. CPI deflator. Henceforth we will refer to our relative price index of finished goods as the relative price of imports. For our measure of the real exchange rate, we use the Federal Reserve's real effective exchange rate, which is constructed from data on nominal exchange rates and consumer price indices for 39 countries.

We use the following statistic to summarize the relationship between these two series is:

$$
\beta_{p_{m}, q}=\frac{\operatorname{cov}\left(p_{m}, q\right)}{\sigma_{q}^{2}}=\operatorname{corr}\left(p_{m}, q\right) \frac{\sigma_{p_{m}}}{\sigma_{q}},
$$

where $p_{m}$ denotes the relative price of imports and $q$ denotes the real exchange rate. This statistic takes into account the correlation between the two series as well as their relative volatility and can be derived as the estimate from a univariate least squares regression of the real exchange rate on the relative import price. As shown in Table 1, our estimate of $\beta_{p_{m}, q}$ has declined in the 1990s, reflecting both the decline in the relative volatility of import prices and the lower correlation between the two series. Further evidence of the increasing disconnect between these variable is shown in the bottom panel of Figure 1 which plots estimates of $\beta_{p_{m}, q}$ for the log-differenced data based on 10-year, rolling windows (The line with stars indicates the point estimate and the shaded region denotes the 95 percent confidence region.) There is a gradual decline in $\beta_{p_{m}, q}$ beginning in the mid-1980s.

Our summary statistic, $\beta_{p_{m}, q}$, is closely related to estimates of pass-through in empirical studies. For instance, we get comparable estimates to Marazzi, Sheets, and Vigfusson (2005) regarding the change in the relationship between import prices and the exchange rate. ${ }^{1}$ When estimating pass-through, Marazzi, Sheets, and Vigfusson (2005) control for movements

\footnotetext{
${ }^{1}$ When estimating pass-through, Marazzi, Sheets, and Vigfusson (2005) control for movements in marginal costs using foreign CPIs and commodity prices. The results are also similar if different control variables are used. For instance, pass-through declines to the same extent when unit labor costs and domestic output are
} 
in marginal costs using foreign CPIs and commodity prices. The results are also similar if different control variables are used. For instance, pass-through declines to the same extent when unit labor costs and domestic output are respectively used to control for changes in marginal costs and import demand, as in Campa and Goldberg (2004) Overall, the evidence suggests that there has been an increasing disconnect between the price of imported finished goods and the exchange rate. ${ }^{2}$

\section{Trade Costs and Productivity}

In this section, we address the time series evidence regarding whether tariffs and transport costs have fallen over time as well as discuss the behavior for other forms of trade costs. We also examine the data on changes in the relative productivity of the United States vis-à-vis its trading partners.

Barriers to international trade take many forms, some less tangible than others. Typically, tariffs and transport costs come to mind as factors impeding the flow of goods across countries. However, international trade can also be hindered by the presence of legal and regulatory costs, distribution costs, and institutional and cultural barriers. Although tariffs and transport costs make up only a fraction of overall trade costs, they remain an important factor underlying the movement towards greater trade integration. For instance, Baier and Bergstrand (2001) find that the decline in tariff rates and transport costs played an important role in post-World-War-II expansion in international trade for OECD countries. ${ }^{3}$

Data on tariffs and transport costs support the notion that trade costs have been falling over time. For the United States, detailed information on tariffs and transport costs are available from Feenstra (1996) and Feenstra, Romalis, and Schott (2002) who have compiled product-

respectively used to control for changes in marginal costs and import demand, as in Campa and Goldberg (2004).

2 This decline in pass-through is most evident for finished goods. The decline in pass-through for total imports is smaller and less precisely estimated.

3 The fact that tariff and transport costs have been declining throughout the post-war period yields the implication in our model that, other things equal, exchange-rate pass-through to import prices should have declined throughout the post-war period. Unfortunately, our measure of import prices for finished goods industries does not extend back far enough to investigate this possibility. 
level import data. Using this data, we compute tariffs and transport costs for finished-goods industries from 1980 to 2001. For each available industry, we measure trade costs as the sum of transport costs and tariffs and compute an industry-weighted average trade cost measure. (See the appendix of Gust, Leduc, and Vigfusson (2010), for the details of these calculations.)

Figure 2 reports that, over our sample period, the average trade cost across industries fell from 11.1 percent of the custom value of the goods in 1980 to 5.2 percent in 2001. The figure also decomposes our average trade cost measure into its tariffs and transport costs components. It shows that transport costs have declined somewhat since 1980 but that the fall in trade costs has been driven mostly by a reduction in tariffs.

Although tariffs and transport costs have the advantage of being relatively easier to quantify, it is more difficult to measure precisely other forms of trade costs, since they are often not directly observable. As a result, researchers infer these costs by estimating gravity models of international trade. This literature finds mixed evidence regarding a possible decline in overall trade costs. ${ }^{4}$ As a result, we take a conservative approach and focus only on the evidence regarding transport costs and tariffs.

Since trade integration can also be triggered by improved productivity of exporting firms, we document changes in relative productivity across countries. The top panel of Figure 3 displays the annualized percentage change in GDP per employee for the United States ('US'), its foreign counterpart ('ROW'), and other regions around the world for the 1980-2003 period. ${ }^{5}$ These indices are constructed using data on GDP per employee, and the ROW index is based on data for OECD and major developing countries. Growth in GDP per employee outside the United States outpaced U.S. growth largely due to faster productivity growth in developing Asia ('DA'), which includes a number of rapidly-developing countries such as China and South Korea. Productivity growth in Europe ('EU') was roughly on par with growth in the United

\footnotetext{
4 Using different datasets and methodologies, Rauch (1999), Coe, Subramanian, Tamirisa, and Bhavnani (2002), and Brun, Carrere, Guillaumont, and de Melo (2005) find that trade costs have fallen continuously since the 1970s. On the other hand, Frankel (1997) and Berthelon and Freund (2004) find no evidence of a significant decline in trade costs.

${ }^{5}$ Although we would prefer a more disaggregated measure, we focus on productivity at the aggregate level due to data limitations for developing countries.
} 
States, while Japanese ('JA') productivity growth was somewhat faster than in the United States, despite a marked deceleration in Japanese productivity in the 1990s.

With foreign labor productivity growth higher than U.S. productivity growth over the last two decades, there has been considerable convergence of foreign productivity to the level of U.S. productivity. The bottom panel of Figure 3 shows that GDP per employee outside the United States roughly doubled over the 1980-2003 period, while U.S. GDP per employee rose about 40 percent over this period. As a consequence, the level of foreign productivity has increased by 40 percent relative to U.S. productivity over the past twenty-five years.

\section{The Model}

Our model is based on Gust, Leduc, and Vigfusson (2010), and consists of a home and a foreign economy. These two economies have isomorphic structures so in our exposition we focus on describing only the domestic economy. The domestic economy consists of two types of agents: households and firms. Households have utility that depends on the consumption of both domestically-produced goods and imported goods. These goods are purchased from monopolistically competitive firms, who set prices flexibly each period. While the range of goods produced by these firms is exogenously given, the fraction of firms that export is determined endogenously. In particular, because a firm must pay both a fixed and variable cost to export its good, it may choose to sell its good only in the domestic economy. The key element we introduce into this environment is that a firm's demand curve has a non-constant elasticity so that exchange-rate pass-through to import prices may be incomplete.

\subsection{Households}

The utility function of the representative household in the home country is

$$
E_{t} \sum_{j=0}^{\infty} \beta^{j}\left\{\log \left(C_{t+j}\right)-\chi_{0} \frac{L_{t+j}^{1+\chi}}{1+\chi}\right\}
$$


where the discount factor $\beta$ satisfies $0<\beta<1$ and $E_{t}$ is the expectation operator conditional on information available at time $t$. The period utility function depends on consumption $C_{t}$ and labor $L_{t}$. A household also purchases state-contingent assets $b_{t+1}$ that are traded internationally so that asset markets are complete.

Household's receive income from working and an aliquot share of profits of all the domestic firms, $\Omega_{t}$. In choosing its contingency plans for $C_{t}, L_{t}, b_{t+1}$, a household takes into account its budget constraint at each date:

$$
C_{t}+\int_{s} p_{b t, t+1} b_{t+1}-b_{t}=w_{t} L_{t}+\Omega_{t}
$$

In equation (3), $w_{t}=\frac{W_{t}}{P_{t}}$ is household's real wage and $p_{b t, t+1}$ denotes the price of an asset that pays one unit of the domestic consumption good in a particular state of nature at date $t+1$. (For convenience, we have suppressed that variables depend on the state of nature.).

\subsection{Demand Aggregator}

There is a continuum of goods indexed by $i \in[0,1]$ in each economy. While a domestic household purchases all of the domestically-produced goods, there are only $j \in\left[0, \omega_{t}^{*}\right]$ that are available for imports, where $\omega_{t}^{*}$ denotes the endogenously determined fraction of traded foreign goods. A household chooses domestically-produced goods, $C_{d t}(i)$, and imported goods, $C_{m t}(j)$, to minimize their total expenditures:

$$
\left[\int_{0}^{1} P_{d t}(i) C_{d t}(i) d i+\int_{0}^{\omega_{t}^{*}} P_{m t}(j) C_{m t}(j) d j\right],
$$

subject to

$$
\int_{0}^{1} \int_{0}^{\omega_{t}^{*}} D\left(\frac{C_{d t}(i)}{C_{t}}, \frac{C_{m t}(j)}{C_{t}}\right) d i d j=1 .
$$

In minimizing its expenditures, a household takes the prices of the domestic, $P_{d t}(i)$, and imported goods, $P_{m t}(j)$, as given. (For convenience, we denote these prices in nominal terms, although prices are flexible in the model and we solve only for real variables.) In our model, 
there are no distribution services required to sell the imported goods to households. Accordingly, $P_{m t}(j)$ denotes both the retail import price for good $j$ and price charged at the point of entry.

The household's demand aggregator for producing a unit of $C_{t}$ and is defined by:

$$
\int_{0}^{1} \int_{0}^{\omega_{t}^{*}} D\left(\frac{C_{d t}(i)}{C_{t}}, \frac{C_{m t}(j)}{C_{t}}\right) d i d j=\left[\frac{1}{1+\omega_{t}^{*}} V_{d t}^{\frac{1}{\rho}}+\frac{\omega_{t}^{*}}{1+\omega_{t}^{*}} V_{m t}^{\frac{1}{\rho}}\right]^{\rho}-\frac{1}{(1+\eta) \gamma}+1
$$

In this expression, $V_{d t}$ is an aggregator for domestic goods given by:

$$
V_{d t}=\int_{0}^{1} \frac{1}{(1+\eta) \gamma}\left[\left(1+\omega_{t}^{*}\right)(1+\eta) \frac{C_{d t}(i)}{C_{t}}-\eta\right]^{\gamma} d i
$$

and $V_{m t}$ is an aggregator for imported goods given by:

$$
V_{m t}=\frac{1}{\omega_{t}^{*}} \int_{0}^{\omega_{t}^{*}} \frac{1}{(1+\eta) \gamma}\left[\left(1+\omega_{t}^{*}\right)(1+\eta) \frac{C_{m t}(j)}{C_{t}}-\eta\right]^{\gamma} d j .
$$

Our demand aggregator adapts the one discussed in Dotsey and King (2005) to an international environment and is discussed in more detail in Gust, Leduc, and Vigfusson (2010),. It shares the central feature that the elasticity of demand is nonconstant (NCES) with $\eta \neq 0$, and the (absolute value of the) demand elasticity can be expressed as an increasing function of a firm's relative price when $\eta<0$.

Expenditure minimization by a domestic household implies that the demand curve for an imported good is given by:

$$
\frac{C_{m t}(j)}{C_{t}}=\frac{1}{1+\omega_{t}^{*}}\left[\frac{1}{1+\eta}\left(\frac{P_{m t}(j)}{P_{m t}}\right)^{\frac{1}{\gamma-1}}\left(\frac{P_{m t}}{\Gamma_{t}}\right)^{\frac{\rho}{\gamma-\rho}}+\frac{\eta}{1+\eta}\right] .
$$

In the above, $\Gamma_{t}$ is a price index consisting of the prices of a firm's competitors defined as:

$$
\Gamma_{t}=\left[\left(\frac{1}{1+\omega_{t}^{*}}\right) P_{d t}^{\frac{\gamma}{\gamma-\rho}}+\left(\frac{\omega_{t}^{*}}{1+\omega_{t}^{*}}\right) P_{m t}^{\frac{\gamma}{\gamma-\rho}}\right]^{\frac{\gamma-\rho}{\gamma}}
$$

and $P_{d t}$ and $P_{m t}$ are indices of domestic and import prices defined as:

$$
\begin{aligned}
& P_{d t}=\left(\int_{0}^{1} P_{d t}(i)^{\frac{\gamma}{\gamma-1}} d i\right)^{\frac{\gamma-1}{\gamma}}, \\
& P_{m t}=\left(\frac{1}{\omega_{t}^{*}} \int_{0}^{\omega_{t}^{*}} P_{m t}(j)^{\frac{\gamma}{\gamma-1}} d j\right)^{\frac{\gamma-1}{\gamma}} .
\end{aligned}
$$


Expenditure minimization also implies an analogous expression for the demand curve of domestic good $i$, which depends on prices, $P_{d t}(i), P_{d t}$, and $\Gamma_{t}$.

A property of our aggregator is that it nests an Armington aggregator so that the elasticity of substitution between a home and foreign good can differ from the demand elasticity for two home goods. ${ }^{6}$ This separate elasticity for goods occurs when $\rho \neq 1$, which gives the model more flexibility to match estimates of the elasticity of substitution between home and foreign tradeables as well as estimates of economy-wide markups. More importantly, when $\eta \neq 0$, the demand curve has an additive linear term, which implies that the elasticity of demand depends on the price of good $i$ relative to other prices. It is this feature that helps give rise to incomplete pass-through to import prices and implies that pass-through depends on the economy's structure including the underlying shocks.

The aggregate consumer price level is given by

$$
P_{t}=\frac{1}{1+\eta} \Gamma_{t}+\frac{\eta}{1+\eta}\left[\frac{1}{1+\omega_{t}^{*}} \int_{0}^{1} P_{d t}(i) d i+\frac{1}{1+\omega_{t}^{*}} \int_{0}^{\omega_{t}^{*}} P_{m t}(j) d j\right] .
$$

From this expression, it is clear that the consumer price level is equal to the competitive pricing bundle, $\Gamma_{t}$, when $\eta=0$. In general, the consumer price level is the sum of $\Gamma_{t}$ with a linear aggregator of prices for individual goods. ${ }^{7}$

\subsection{Firms}

The production function for firm $i$ is linear in labor so that

$$
Y_{t}(i)=Z_{t} L_{t}(i)
$$

${ }^{6}$ More specifically, with $\eta=0$, our demand aggregator can be thought of as the combination of a Dixit-Stiglitz and Armington aggregator. To see this, note that in this case we can rewrite our aggregator as:

$$
C_{t}=\left(1+\omega_{t}^{*}\right)\left[\frac{1}{1+\omega_{t}^{*}} C_{d t}^{\frac{\gamma}{\rho}}+\frac{\omega_{t}^{*}}{1+\omega_{t}^{*}} C_{m t}^{\frac{\gamma}{\rho}}\right]^{\frac{\rho}{\gamma}},
$$

where $C_{d t}=\left(\int_{0}^{1} C_{d t}(i)^{\gamma} d i\right)^{\frac{1}{\gamma}}$ and $C_{m t}=\left(\frac{1}{\omega_{t}^{*}} \int_{0}^{\omega_{t}^{*}} C_{m t}(j)^{\gamma} d j\right)^{\frac{1}{\gamma}}$. As in Bergin and Glick (2007), our specification of the demand aggregator also rules out the "love of variety" effect. However, a change in $\omega_{t}^{*}$ does increase the number of foreign varieties relative to home varieties in the consumption bundle, and thus "home" bias in household preferences is endogenously determined in the model.

7 The consumer price level can be derived from equating equation (4) to $P_{t} C_{t}$ and substituting in the relative demand curves. The price $\Gamma_{t}$ can be derived from substituting the relative demand curves into equation (5). 
In the above, $Z_{t}$ is an aggregate, iid technology shock that affects the production function for all firms in the home country. A firm hires labor in a competitive market in which labor is completely mobile within a country but immobile across countries. Marginal cost is therefore the same for all firms in the home country so that real marginal cost of firm $i$ is given by $\frac{w_{t}}{Z_{t}}$.

Firms in each country are monopolistically competitive and each firm sells its good to households located in its country. Profit maximization implies that a firm chooses to set its price as a markup over marginal cost. As a result, the price of good $i$ in the domestic market satisfies:

$$
\frac{P_{d t}(i)}{P_{t}}=\mu_{d t}(i) \frac{w_{t}}{Z_{t}}, \quad i \in[0,1]
$$

with $\mu_{d t}(i) \geq 1$. The markup $\mu_{d t}(i)$ can be expressed as:

$$
\mu_{d t}(i)=\mu_{d t}=\left[1-\frac{1}{\left|\epsilon_{d t}\right|}\right]^{-1}=\left[\gamma+\eta(\gamma-1)\left(\frac{P_{d t}}{\Gamma_{t}}\right)^{\frac{\rho}{\rho-\gamma}}\right]^{-1}
$$

where $\left|\epsilon_{d t}\right|$, is the absolute value of the elasticity of a domestic good given by:

$$
\epsilon_{d t}=\left[(\gamma-1)\left(1+\eta\left(\frac{P_{d t}}{\Gamma_{t}}\right)^{\frac{\rho}{\rho-\gamma}}\right)\right]^{-1}
$$

In the above, we have dropped the index $i$, since we restrict our attention to a symmetric equilibrium in which all firms set the same price in the domestic market (i.e., $P_{d t}(i)=P_{d t}$, $\epsilon_{d t}(i)=\epsilon_{d t}$, and $\left.\mu_{d t}(i)=\mu_{d t}.\right)$

Equation (15) shows that a firm's markup depends on the price it sets relative to its competitors price $\Gamma_{t}$. When the (absolute value of) the demand elasticity is increasing in $\frac{P_{d t}}{\Gamma_{t}}$, the markup will be a decreasing function of this relative price. Consequently, a firm will respond to a fall in the price of its competitors by lowering its markup and price. A firm finds it desirable to do so, because otherwise it will experience a relatively large fall in its market share. An important exception to this pricing behavior is the CES demand curve in which $\eta=0$. In this case, a firm's markup does not depend on the relative price of its competitors. 


\subsubsection{Entry}

Following Melitz (2003), Ghironi and Melitz (2005) and Bergin and Glick (2007), we allow for the endogenous entry and exit of firms into the export market. In particular, we assume that each period a firm faces a fixed and per-unit export cost and decides whether to export or not. Unlike these previous papers, which allow productivity to vary with a good's type, we assume that the fixed cost varies with the variety of the good. ${ }^{8}$ In particular, we assume that the fixed cost is given by:

$$
f_{x}(i)=f_{x}\left(\frac{1}{1-\alpha_{x} i}-1\right), \quad \alpha_{x} \geq 0
$$

and is paid in units of labor. We view this fixed cost as reflecting the cost to a firm of making consumers aware of its product, setting up a distribution system, and understanding the legal and regulatory environment of a foreign market. It seems reasonable to assume that these costs differ depending on the type of good.

Since an exporter must make its entry decision before the realization of shocks in period $t$, a firm will choose to export if its expected profits from exporting exceed its fixed cost:

$$
E_{t-1}\left[\left(\pi_{x t}(i)-f_{x}(i) w_{t}\right)\right]>0
$$

where exporter $i$ 's per-unit profits in the foreign market are given by:

$$
\pi_{x t}(i)=\left(q_{t} \frac{P_{m t}^{*}(i)}{P_{t}^{*}}-\frac{D_{t} w_{t}}{Z_{t}}\right) C_{m t}^{*}(i)
$$

In the above, $q_{t}$ is the real exchange rate expressed in units of the home consumption bundle per units of foreign consumption, $P_{m t}^{*}(i)$ is the nominal price of home good $i$ denominated in foreign currency, and $C_{m t}^{*}(i)$ is the demand for home good $i$ by foreign households. (We use a star to denote foreign variables.) Also, $D_{t}$ is an iceberg shipping cost which we assume to be a stochastic iid process. ${ }^{9}$ Finally, our functional form for the fixed cost implies that only firms

\footnotetext{
8 In our environment with variable markups, heterogeneity in the technologies of firms would considerably complicate the analysis, since computing aggregate prices and quantities would involve accounting for a distribution of markups. In contrast, because the fixed cost does not affect a firm's marginal pricing condition, we can still analyze a symmetric equilibrium in which all firms who decide to export choose the same price and markup.

9 This assumption is not critical for our analysis. We assume that $D_{t}$ is stochastic mainly to illustrate how pass-through differs depending on the type of shock.
} 
on the interval $i \in\left[0, \omega_{t}\right]$ will export their good where the marginal good $\omega_{t}$ satisfies equation (18) as an equality.

Similar to a firm's pricing decision in the domestic market, profit maximization implies that a firm chooses its export price as a markup over marginal cost:

$$
q_{t} \frac{P_{m t}^{*}(i)}{P_{t}^{*}}=\mu_{m t}^{*}(i) \frac{D_{t} w_{t}}{Z_{t}}, \quad i \in\left[0, \omega_{t}\right]
$$

In a symmetric equilibrium, all exporting firms will choose the same price and markup (i.e., $P_{m t}^{*}(i)=P_{m t}^{*}$ and $\left.\mu_{m t}^{*}(i)=\mu_{m t}^{*}\right)$. An exporter's markup is given by:

$$
\mu_{m t}^{*}(i)=\mu_{m t}^{*}=\left[1-\frac{1}{\left|\epsilon_{m t}^{*}\right|}\right]^{-1}=\left[\gamma+\eta(\gamma-1)\left(\frac{P_{m t}^{*}}{\Gamma_{t}^{*}}\right)^{\frac{\rho}{\rho-\gamma}}\right]^{-1}
$$

where $\left|\epsilon_{m t}^{*}\right|$ is the absolute value of the elasticity of a domestic good in the foreign market.

Comparing equations (14) and (20), we note that the law of one price (i.e., $\frac{P_{m t}^{*}(i)}{P_{t}^{*}} q_{t}=\frac{P_{d t}(i)}{P_{t}}$ ) will not hold when $D_{t}>1$. In addition, because the demand elasticity can differ across markets (i.e., $\epsilon_{d t} \neq \epsilon_{m t}^{*}$ ), a firm will optimally choose to price discriminate. Price discrimination by firms is possible due to the presence of fixed and per-unit trade costs.

\section{Defining Pass-Through}

We consider two alternative definitions for import price pass-through. For the first, we define pass-through from the perspective of an individual exporter who views the exchange rate as exogenous. This definition considers how much an individual exporter changes his price in response to a one percent change in the exchange rate, holding constant the other factors a firm takes as given: its marginal cost and the prices of other firms. Letting $p_{m t}(j)=\frac{P_{m t}(j)}{P_{t}}$ and $\xi_{t}=\frac{\Gamma_{t}}{P_{t}}$ denote the relative price of exporter $i$ and the relative price of its competitors, respectively, a foreign exporter's pricing equation can be written as:

$$
p_{m t}(j)=\mu_{m t}(j) D_{t}^{*} \frac{w_{t}^{*}}{Z_{t}^{*}} q_{t},
$$


where $\mu_{m t}(j)$ is given by an analagous expression to equation (21). The direct effect of an exchange rate change on the price of foreign exporter $i$ is given by $\kappa_{m t}(j)=\frac{\partial p_{m t}(j)}{\partial q_{t}} \frac{q_{t}}{p_{m t}(j)}$ :

$$
\kappa_{m t}(j)=\frac{1}{1-\eta \mu_{m t}(i)\left(\frac{\rho(\gamma-1)}{\gamma-\rho}\right)\left(\frac{p_{m t}(j)}{\xi_{t}}\right)^{\frac{\rho}{\rho-\gamma}}}=\frac{1}{1+\left(\mu_{m t}(j)-1\right) \frac{\partial\left|\epsilon_{m t}(j)\right|}{\partial p_{m t}(j)} \frac{p_{m t}(j)}{\left|\epsilon_{m t}(j)\right|}} .
$$

Because $\kappa_{m t}(j)$ measures only the direct effect of an exchange rate change on an exporter's price, we refer to it as the direct pass-through measure.

From the expression directly after the equality, we can see that if $\eta<0$ then direct passthrough will be incomplete. ${ }^{10}$ In this case, a one percent increase in $q_{t}$ drives up a foreign exporter's cost when denominated in dollars; however, a firm does not raise its price a full one percent because as the exporter's price rises relative to its competitors, it induces the exporter to accept a lower markup rather than give up market share.

Alternatively, the expression after the second equality in equation (23) indicates that direct pass-through depends on the level of the markup and the elasticity of the elasticity of demand, $\frac{\partial\left|\epsilon_{m t}(j)\right|}{\partial p_{m t}(j)} \frac{p_{m t}(j)}{\left|\epsilon_{m t}(j)\right|}$. This expression is similar to the one derived by Eichenbaum and Fisher (2007) in a closed economy context. With $\eta<0$, the elasticity of the elasticity of demand is positive and as a result $\kappa_{m t}(j)<1$.

To facilitate comparisons of our model with the data, in addition to our direct passthrough measure, we also examine our model's implications for the second moment $\beta_{p_{m}, q}$ previously defined (in log-differences) as:

$$
\beta_{p_{m}, q}=\frac{\operatorname{cov}\left(\Delta p_{m t}, \Delta q_{t}\right)}{\operatorname{var}\left(\Delta q_{t}\right)}
$$

The relationship between $\beta_{p_{m}, q}$ and $\kappa_{m t}(j)$ can be seen by log-linearizing equation (22) around the non-stochastic steady state to write a foreign exporter's pricing decision as:

$$
\hat{p}_{m t}=\kappa_{m}\left(\hat{D}_{t}^{*}+\hat{\psi}_{t}^{*}+\hat{q}_{t}\right)+\left(1-\kappa_{m}\right) \hat{\xi}_{t} .
$$

The symbol “^' denotes the log-deviation of a variable from its steady state value and $\kappa_{m}=\kappa_{m}(i)$ evaluated at nonstochastic steady state. Using this equation, we can relate $\beta_{p_{m}, q}$ and $\kappa_{m}$ via:

$$
\beta_{p_{m}, q}=\kappa_{m}+\kappa_{m}\left(\frac{\operatorname{cov}\left(\Delta \psi_{t}^{*}, \Delta q_{t}\right)}{\operatorname{var}\left(\Delta q_{t}\right)}+\frac{\operatorname{cov}\left(\Delta D_{t}^{*}, \Delta q_{t}\right)}{\operatorname{var}\left(\Delta q_{t}\right)}\right)+\left(1-\kappa_{m}\right) \frac{\operatorname{cov}\left(\Delta \xi_{t}, \Delta q_{t}\right)}{\operatorname{var}\left(\Delta q_{t}\right)} .
$$

\footnotetext{
${ }^{10}$ With $\eta<0$, the demand curve is less convex than the CES case.
} 
According to equation (26), the univariate regression statistic, $\beta_{p_{m}, q}$, is related to $\kappa_{m}$ except that $\beta_{p_{m}, q}$ takes into account any correlation of the real exchange rate with an exporter's costs and the pricing index of an exporter's competitors that occurs in general equilibrium. Thus, $\beta_{p_{m}, q}$ takes into account both direct and indirect effects of an exchange rate change on an exporter's price.

In our analysis, we focus on comparing our model results to the data for $\beta_{p_{m}, q}$ rather than $\kappa_{m}$. This reflects that $\beta_{p_{m}, q}$ is a second moment that is easily measured in the data. In contrast, measuring $\kappa_{m}$ is complicated by finding good measures of marginal costs and the prices of a firm's competitors as well as correctly specifying the equations for estimating $\kappa_{m}$ and dealing with the endogeneity of the exchange rate and the prices of other firms.

\section{Calibration}

In order to investigate the role of trade costs and productivity differentials on pass-through, we log-linearize and solve the model around two different steady states. In the first, the home and foreign economies are identical, and both economies have relatively high trade costs. We call this our benchmark calibration. In the second, we lower trade costs as well as raise the level of foreign productivity, keeping the remaining parameters constant. ${ }^{11}$ We call this the 2004 calibration. ${ }^{12}$

The value of $\eta$, which governs the curvature of the demand curve, is critical for our analysis. Faced with sparse independent evidence regarding this parameter, we calibrate it as a part of a simulated method of moments procedure. Specifically, we choose $\eta$ along with the standard deviations of the iid technology and trade cost shocks so that the model's implications for the volatility of output, the ratio of the volatility of relative import prices to the real exchange

\footnotetext{
${ }^{11}$ While the level of foreign productivity is actually lower than U.S. productivity, for simplicity we begin with a calibration in which the two economies are identical. This simplification seems reasonable, since our results for the decline in pass-through depend critically on the change in relative productivity in the two countries rather than their initial levels.

12 In the initial steady state, each country's net foreign asset position is zero. Given this initial position, we then allow a country's net foreign asset position to respond endogenously in the second steady state to the deterministic change in trade costs and foreign productivity.
} 
rate, and the correlation between relative import prices and the real exchange rate match those observed in the 1980-1989 period. In doing so, we constrain the standard deviation of the technology shocks and trade costs shocks to be the same in both countries (i.e., $\sigma_{z}=\sigma_{z}^{*}$ and $\left.\sigma_{D}=\sigma_{D^{*}}\right)$. By construction, our model matches the observed value of $\beta_{p_{m}, q}$ for the 1980s. With $\eta$ pinned down based on the pre-1990s data, we then examine the fall in $\beta_{p_{m}, q}$ arising from a fall in trade costs and a higher level of foreign productivity.

Tables 2 show our calibrated value of $\eta$ as well as the calibrated values of other important parameters of the model. We choose $\gamma$ to be consistent with an exporter's markup over marginal cost of around 20 percent in the benchmark calibration. We set $\rho=0.85$, which implies an aggregate trade-price elasticity for the benchmark calibration of $2 .{ }^{13}$ The discount factor $\beta=1.03^{-0.25}$, and the utility function parameter $\chi$ is set to 1.5 , which implies a Frisch elasticity of labor supply of $2 / 3$. We set $\chi_{0}$ and $\chi_{0}^{*}$ to imply $L=L^{*}=1$ in the benchmark calibration.

For the initial levels of technology, we choose $Z=Z^{*}=1$. As shown in Figure 3, foreign productivity rose about 35 percent relative to the level of U.S. productivity from 1980 to 2000. Thus, we set $Z^{*}=1.35$ in the 2004 calibration. Consistent with Figure 2 , we set $D=D^{*}=1.1$ in the benchmark calibration and lowered $D=D^{*}=1.05$ in the 2004 calibration.

For the fixed costs of trade we set $f_{x}=f_{x}^{*}=0.46$ which implies that the import share in the home economy is about 10 percent. Since we assume that trade is balanced in the initial steady state, the foreign economy has the same import share. We choose $\alpha_{x}=\alpha_{x}^{*}=2.5$ so that after the fall in trade costs and increase in foreign productivity, the home country's import share rises about 4 percentage points.

We also compare our benchmark calibration to one with CES preferences (i.e., $\eta=0$ ). Table 2 reports the parameter values used for the CES calibration, which were selected in an analogous manner to our benchmark calibration. Table 3 shows that both the CES and

\footnotetext{
${ }^{13}$ We define the aggregate trade-price elasticity by differentiating aggregate import demand:
}

$$
\omega_{t}^{*} C_{m t}=\frac{\omega_{t}^{*}}{1+\omega_{t}^{*}}\left[\frac{1}{1+\eta}\left(\frac{P_{m t}}{\Gamma_{t}}\right)^{\frac{\rho}{\gamma-\rho}}+\frac{\eta}{1+\eta}\right] C_{t},
$$

with respect to $\frac{P_{m t}}{\Gamma_{t}}$ holding $C_{t}$ and $\omega_{t}^{*}$ constant. With $\rho<1$ in our benchmark calibration, this aggregate elasticity is lower than the elasticity of demand for individual good i, $\left|\epsilon_{m t}(i)\right|$. 
benchmark calibration (by construction) match the observed volatility of output and correlation between import prices and the exchange rate in the 1980s. However, only the benchmark calibration with $\eta \neq 0$ has the flexibility to match the observed value of $\beta_{p_{m}, q}$ in the 1980s. Although the benchmark calibration implies slightly more exchange rate volatility than the CES calibration, both versions of the model understate the amount of volatility relative to the data. Thus, while the NCES demand curves better account for the observed relationship between the relative import price and the real exchange rate, they do not by themselves explain other important aspects of the data emphasized in the international business cycle literature. ${ }^{14}$

\section{Results}

In this section, we first discuss the effects of falling trade costs and higher foreign productivity on pass-through. ${ }^{15}$ We then present our main finding regarding how pass-through is influenced by firms' entry in the export market.

\subsection{Trade Integration and Declining Pass-Through}

Table 4 shows the effects of lowering per-unit trade costs and higher foreign productivity on pass-through and important steady state prices and quantities. The table shows the value of the variables in steady state except for $\beta_{p_{m}, q}$, which is obtained from log-linearizing the model and computing the population moments of the model's variables given the shock processes. We start by looking at the effects of changing one variable at a time (columns 2, 3 and 5), before analyzing their combined impacts (last column). As shown in the second column, a five percentage point fall in the trade costs of foreign exporters reduces the real marginal cost of exporting (denominated in terms of the home consumption bundle) by 3.5 percent. Note that the fall in foreign exporters' real marginal cost, $q D^{*} \frac{w^{*}}{Z^{*}}$, is less than the decline in $D^{*}$ as

\footnotetext{
${ }^{14}$ See Bergin and Feenstra (2001) for a discussion of how the interaction of NCES demand curves with sticky prices denominated in local currency can be helpful in accounting for exchange rate dynamics.

${ }^{15}$ More details on the theoretical link between trade integration and pass-through can be found in Gust, Leduc, and Vigfusson (2010).
} 
increased demand for the foreign good puts upward pressure on the real exchange rate, $q$, and on foreign wages. With lower costs, foreign exporters reduce their prices and the home country's import share rises 0.7 percentage point. Because foreign exporters' prices fall relative to their competitors (i.e., the domestic firms), they are able to increase their markups and still gain market share. Conversely, the prices for domestic goods rise relative to their competitors, and domestic firms are forced to cut their markups in reaction to stiffer competition from abroad.

With higher markups on foreign goods, the strategic complementarity intensifies and foreign exporters become more willing to vary their markups in response to cost shocks. Thus, the 5 percentage point decline in trade costs causes the direct pass-through measure $\kappa_{m}$ to fall from 0.48 to 0.462 , or 1.8 percentage points. This fall in $\kappa_{m}$ also leads to a reduction in our statistical measure of pass-through, $\beta_{p_{m}, q}$, of 2.3 percentage points. To understand the fall in $\beta_{p_{m}, q}$, recall that equation (26, reproduced below) implies a fall in $\kappa_{m}$ directly lowers $\beta_{p_{m}, q}$ :

$$
\beta_{p_{m}, q}=\kappa_{m}+\kappa_{m}\left[\frac{\operatorname{cov}\left(\Delta \psi_{t}^{*}, \Delta q_{t}\right)}{\operatorname{var}\left(\Delta q_{t}\right)}+\frac{\operatorname{cov}\left(\Delta D_{t}^{*}, \Delta q_{t}\right)}{\operatorname{var}\left(\Delta q_{t}\right)}\right]+\left(1-\kappa_{m}\right)\left[\frac{\operatorname{cov}\left(\Delta \xi_{t}, \Delta q_{t}\right)}{\operatorname{var}\left(\Delta q_{t}\right)}\right] .
$$

Moreover, the decline in $\kappa_{m}$ implies that there is less weight on the marginal cost term (the first term in square brackets) and more weight on the price competitiveness term (the second term in square brackets). The marginal cost term is larger than the price competitiveness term because $\xi_{t}$ has little variation. As a result, a fall in $\kappa_{m}$, by shifting a firm's emphasis in pricing away from cost considerations to considerations of price competitiveness, induces an even larger decline in $\beta_{p_{m}, q}$.

A fall in $D$, the trade cost on domestic goods sold to the foreign economy, also lowers passthrough (third column of Table 4). In general equilibrium, increased foreign demand for home goods causes an appreciation of the home currency that reduces the cost of foreign exporters and leads to a fall in pass-through. The appreciation of the currency results in the real cost of foreign exporters (in home currency) falling by 0.7 percent. This decline in costs triggers a fall in foreign exporters' prices relative to prices of domestic goods in the home market. As a result, exporters increase their markups and prices of foreign goods decline only 0.3 percent. At these higher markups, $\kappa_{m}$ declines 0.4 percentage point and $\beta_{p_{m}, q}$ declines 0.6 percentage points. 
The fourth column of Table 4 shows the combined effects of lowering trade costs in the home and foreign economies. In this case, foreign exporters' share of the domestic market expands by 0.9 percentage point and our statistical measure of pass-through declines about 3 percentage points.

The fifth column of Table 4 displays the effects of raising the level of foreign productivity by 35 percent. Although there is a substantial increase in foreign real wages in response to the higher level of productivity, marginal costs in foreign currency fall. The foreign currency also depreciates; so, an exporter's marginal cost in home currency units falls almost 19 percent. This large decline in foreign costs allows foreign exporters to both substantially reduce prices and expand their markups at the expense of their domestic competitors. Consequently, the decline in $\beta_{p_{m}, q}$ is a sizeable 12.5 percentage points.

The last column of Table 4 displays the decline in pass-through from the benchmark calibration to 2004 calibration in which the increase in foreign productivity is combined with the decline in $D$ and $D^{*}$. Higher productivity and lower trade costs have a substantial impact on pass-through. Overall, $\beta_{p_{m}, q}$ falls almost 15 percentage points, which accounts for about one third of the observed decline. The fall in pass-through occurs even though the home market is simultaneously becoming more competitive: markups on domestic goods fall 1.7 percentage points (see Table 2 for a more detailed comparison of the properties of the benchmark and 2004 calibrations). These results broadly capture the view that pass-through has fallen in the United States because of increased foreign competition, which in turn has reduced profit margins of domestic producers in the U.S. market. ${ }^{16}$

\subsection{The Impact of Entry on Pass-Through}

We now assess the interaction of the intensive and extensive trade margins with the variable demand elasticity strategic and their role in accounting for the decline in pass-through. To do this, we consider a version of our model that abstracts from entry altogether and then consider a

\footnotetext{
${ }^{16}$ In recent years, U.S. producers have experienced increased profits. If we allowed U.S. productivity to rise as in Figure 3 instead of fixing $Z=1$ in both steady states, U.S. profits would also rise despite a fall in domestic markups of U.S producers.
} 
version in which only foreign exporters make entry decisions. In each case, we consider a fall in domestic and foreign trade costs of 5 percentage points and an increase in foreign productivity of 35 percent.

To better understand the relative importance of the intensive and extensive margins, Figure 4 plots a number of key variables as a function of the number of foreign exporters. We do so for three different cases: the benchmark calibration with relatively high trade costs and low foreign productivity (the dashed blue line), the 2004 calibration with low trade costs and high foreign productivity (the dotted red line), and the 2004 calibration except only foreign exporters make entry decisions (the dashed-dotted green line). The corresponding numerical results to Figure 4 are shown in Table 5.

Consider first the dashed blue lines in each panel. As the number of foreign exporters increases, per-unit profits of export good $i$ decline due to lower demand for each individual good and a decline in an exporter's markup. This markup decline reflects that an increase in the number of foreign exporters drives up wages and production costs in the foreign economy, inducing a real home currency depreciation and a rise in the relative import price, $p_{m}$. Conversely, the markups of domestic firms in the domestic market increase.

Both measures of pass-through increase as the number of foreign exporters rises. As discussed earlier, this increase reflects that a reduction in an exporter's markup is associated with an increase in direct pass-through, $\kappa_{m}$. Also, an increase in the number of exporters in the domestic economy implies that there are more firms who change their prices in response to exchange-rate movements, which also increases pass-through in general equilibrium, $\beta_{p_{m}, q}$. Thus, as in Dornbusch (1987), our model implies that other things equal, an increase in the number of foreign exporters leads to higher pass-through of exchange rate changes to import prices.

Returning to the upper left panel, the equilibrium number of foreign exporters in the benchmark calibration is given by point A where per-unit profits intersect with the fixed cost (the solid black line). What happens when we lower trade costs and raise foreign productivity but completely abstract from the extensive trade margin? The equilibrium shifts from point A 
to point $\mathrm{B}$, as the fall in export production costs raises the demand for an exporter's good as well as his profits. As shown in the upper right panel, the import share in the home economy also rises from about 10 percent to 10.7 percent. Lower production costs are also associated with an increase in the markups of foreign exporters and, as shown in the second column of Table 5, a decline in pass-through of about 15.1 percentage points. Consequently, most of the decline in pass-through occurs along the intensive trade margin.

Now consider the case in which we allow for the entry of foreign exporters in response to the decline in the cost of exporting. In this case, the equilibrium shifts from point B to point $\mathrm{C}$, as the increase in profits induces more exporters to pay their fixed entry cost. Accordingly, the import share now rises to about 14.6 percent, so that the bulk of the increase in imports reflects new goods. There is some decline in the markups of foreign exporters relative to point B. Although the two measures of pass-through rise from point $\mathrm{C}$ to point $\mathrm{B}$, the effect is small relative to the decline in pass-through associated with the intensive margin.

When we further endogenize home exporters' entry decisions, the equilibrium moves from point $\mathrm{C}$ to point $\mathrm{D}$, which corresponds to the last column in Table 5. Since foreign firms are 35 percent more productive than in the initial equilibrium (point A), foreign demand for domestic goods falls and domestic exporters decide to exit the foreign market. Table 5 shows that this reduction in the number of domestic exporters implies a smaller appreciation of the domestic real exchange rate and as a result the profit and markup functions for a foreign exporter shifts down to the red dotted line. At equilibrium point $\mathrm{D}$, foreign exporters markups are smaller and, in turn, the direct measure of pass-through, $\kappa_{m}$, is higher than at point C. Despite this increase in $\kappa_{m}, \beta_{p_{m}, q}$ falls, reflecting that there is less co-movement between the real exchange rate and foreign marginal cost (see equation (26)) with a decline in the number of domestic exporters in the foreign economy.

Overall, the entry of foreign exporters plays an important role in accounting for the large rise in the import share associated with a decline in trade costs and higher foreign productivity. An increase in the number of foreign exporters also has the ceteris paribus effect of raising pass-through. However, this effect is small relative to the decline in pass-through that results 
from markup adjustments that occurs along the intensive margin in response to factors that increase trade integration.

\section{Conclusion}

We assessed the impact of firm entry on exchange-rate pass-through to import prices. This question is particularly important given the increased openness of the U.S. economy and the considerable decline in the degree of pass-through to U.S. import prices. Such a decline in pass-through implies that foreign exporters have become more willing to vary their markups in order to keep their local prices competitive and maintain market share in the wake of large exchange rate fluctuations. One argument put forward by those more skeptical of the decline in pass-through is that the entry of foreign exporters associated with greater openness should reduce markups, make them less variable, and raise the degree of exchange rate pass-through.

In our framework, we find that firm entry does indeed push up exchange-rate passthrough and is essential in accounting for the secular rise in the U.S. import share. However, increased entry of foreign exporters has a relatively small impact on exchange rate pass-through. The effects of higher foreign productivity and a reduction in trade costs on markup behavior along the intensive margin are much more important quantitatively and appear to explain a considerable portion of the observed decline in pass-through to U.S. import prices. Thus, it is not surprising that pass-through has declined as the U.S. economy has become more open. 


\section{References}

Baier, S. L. and J. H. Bergstrand (2001). The growth of world trade: Tariffs, transport costs, and income similarity. Journal of International Economics 53, 1-27.

Bergin, P. R. and R. C. Feenstra (2001). Pricing-to-market, staggered contracts, and real exchange rate persistence. Journal of International Economics 54, 333-59.

Bergin, P. R. and R. Glick (2007). Tradability, productivity, and international economic integration. Journal of International Economics 73, 128-151.

Berthelon, M. and C. Freund (2004). On the conservation of distance in international trade. World Bank Policy Research Working Paper 3293.

Brun, J.-F., C. Carrere, P. Guillaumont, and J. de Melo (2005). Has distance died? evidence from a panel gravity model. World Bank Economic Review 19, 99-120.

Campa, J. M. and L. S. Goldberg (2004). Exchange rate pass-through into import prices. Centre for Economic Policy Research Discussion Papers 4391.

Coe, D. T., A. Subramanian, N. T. Tamirisa, and R. Bhavnani (2002). The missing globalization puzzle. International Monetary Fund Working Paper 02/171.

Dornbusch, R. (1987). Exchange rates and prices. American Economic Review 77, 93-106.

Dotsey, M. and R. G. King (2005). Implications of state-dependent pricing for dynamic macroeconomic models. Journal of Monetary Economics 52, 213-42.

Eichenbaum, M. and J. D. M. Fisher (2007). Estimating the frequency of price reoptimization in calvo style models. Journal of Monetary Economics 54, 2032-2047.

Feenstra, R. C. (1996). U.s. imports 1972-1994: Data and concordances. National Bureau of Economic Research Working Paper 5515.

Feenstra, R. C., J. Romalis, and P. Schott (2002). U.s. imports, exports and tariff data, 1989-2001. National Bureau of Economic Research Working Paper 9387.

Frankel, J. A. (1997). Regional Trading Blocs in the World Economic System. Washington, D.C.: Institute for International Economics.

Ghironi, F. and M. J. Melitz (2005). International trade and macroeconomic dynamics with heterogeneous firms. Quarterly Journal of Economics 120, 865-915.

Goldberg, P. K. and M. M. Knetter (1997). Goods prices and exchange rates: What have we learned? Journal of Economic Literature 35, 1243-72.

Gust, C., S. Leduc, and R. Vigfusson (2010). Trade integration, competition, and the decline in exchange rate pass-through. Journal of Monetary Economics 57, 309-324.

Marazzi, M., N. Sheets, and R. J. Vigfusson (2005). Exchange rate pass-through to u.s. import prices: Some new evidence. Board of Governors of the Federal Reserve System International Finance Discussion Papers 833. 
Melitz, M. J. (2003). The impact of trade on intra-industry reallocations and aggregate industry productivity. Econometrica 71, 1695-1725.

Rauch, J. E. (1999). Networks versus markets in international trade. Journal of International Economics 48, 7-35. 
Table 1: Volatility and Correlation of Relative Import Price and Real Exchange Rate ${ }^{a}$

\begin{tabular}{|l|c|c|c|}
\hline Moment (Differenced) & Full Sample & $1980: 1-1989: 4$ & $1990: 1-2004: 4$ \\
\hline a. $\beta_{p_{m}, q}$ & 0.35 & 0.55 & 0.13 \\
$\left(\mathrm{a}=\mathrm{b}^{*} \mathrm{c}\right)$ & 0.47 & 0.60 & 0.25 \\
b. $\sigma_{p_{m}} / \sigma_{q}$ & 0.75 & 0.92 & 0.51 \\
c. $\operatorname{corr}\left(q, p_{m}\right)$ & & & \\
\hline Moment $($ HP-Filtered) & 0.46 & 0.59 & 0.17 \\
\hline a. $\beta_{p_{m}, q}$ & & \\
$\quad\left(\mathrm{a}=\mathrm{b}^{*} \mathrm{c}\right)$ & 0.54 & 0.61 & 0.29 \\
b. $\sigma_{p_{m}} / \sigma_{q}$ & 0.85 & 0.95 & 0.60 \\
c. $\operatorname{corr}\left(q, p_{m}\right)$ & & \\
\hline
\end{tabular}

${ }^{a} \beta_{p_{m}, q}$ denotes the regression coefficient from a univariate least squares regression of the real exchange rate on the relative import price. Differenced refers to data that has been log-differenced. HP-filtered series were computed by transforming the log of the variables (with $\lambda=1600$ ). 
Table 2: Parameter Values and Properties of Calibrated Models

\begin{tabular}{|l|c|c|c|}
\hline & \multicolumn{2}{|c|}{ NCES Demand } & \\
\hline$\rho$ & Benchmark Calibration & 2004 Calibration & CES Calibration \\
$\eta$ & 0.85 & 0.85 & 1.7 \\
$\gamma$ & -3.05 & -3.05 & 0 \\
$\beta$ & 1.1 & 1.1 & 0.835 \\
$\chi$ & 0.9926 & 0.9926 & 0.9926 \\
$\chi_{0}$ & 1.5 & 1.5 & 1.5 \\
$D=D^{*}$ & 0.79 & 0.79 & 0.83 \\
$Z$ & 1.1 & 1.05 & 1.1 \\
$Z^{*}$ & 1 & 1 & 1 \\
$f_{x}$ & 1 & 1.35 & 1 \\
$\alpha_{x}$ & 0.46 & 0.46 & 0.37 \\
$\sigma_{Z}=\sigma_{Z}^{*}$ & 2.5 & 2.5 & 2.5 \\
$\sigma_{D}=\sigma_{D}^{*}$ & 0.0178 & 0.0178 & 0.0191 \\
Home Trade Share & 0.0094 & 0.0094 & 0.008 \\
Home Firms' Domestic Markup $\left(\mu_{d}\right)$ & $10.0 \%$ & $14.0 \%$ & $10.0 \%$ \\
Foreign Exporters' Markup $\left(\mu_{m}\right)$ & 1.27 & 1.24 & 1.20 \\
Home Trade-Price Elasticity & 1.20 & 1.38 & 1.20 \\
Direct Pass-Through $\left(\kappa_{m}\right)$ & -2.0 & -1.2 & -2.0 \\
\hline
\end{tabular}


Table 3: Selected Moments of Data and Calibrated Models ${ }^{a}$

\begin{tabular}{|l|c|c|c|c|c|}
\hline \multirow{2}{*}{ Moment } & \multicolumn{2}{|c|}{ Data } & \multicolumn{3}{c|}{ Model } \\
\cline { 2 - 6 } & $1980-1989$ & $1990-2004$ & $\begin{array}{c}\text { Benchmark } \\
\text { Calibration }\end{array}$ & $\begin{array}{c}2004 \\
\text { Calibration }\end{array}$ & $\begin{array}{c}\text { CES } \\
\text { Calibration }\end{array}$ \\
\hline a. $\beta_{p_{m}, q}=\operatorname{cov}\left(\Delta q, \Delta p_{m}\right) / \operatorname{var}(\Delta q)$ & 0.55 & 0.13 & 0.55 & 0.40 & 1.08 \\
$\quad\left(\mathrm{a}=\mathrm{b}^{*} \mathrm{c}\right)$ & & & & & \\
b. $\sigma\left(\Delta p_{m}\right) / \sigma(\Delta q)$ & 0.60 & 0.25 & 0.60 & 0.43 & 1.17 \\
c. $\operatorname{corr}\left(\Delta q, \Delta p_{m}\right)$ & 0.92 & 0.51 & 0.92 & 0.92 & 0.92 \\
\hline$\sigma\left(y^{h p}\right)$ & 1.74 & 0.98 & 1.74 & 1.71 & 1.74 \\
$\sigma\left(q^{h p}\right)$ & 4.98 & 2.70 & 1.91 & 1.96 & 1.74 \\
\hline
\end{tabular}

${ }^{a}$ The subscript 'hp' denotes that a variable was transformed using the HP-filter (with $\lambda=1600$ ). 
Table 4: The Effect of Permanently Lower Trade Costs and Higher Foreign Productivity ${ }^{a, b}$

\begin{tabular}{|l|c|c|c|c|c|}
\hline & Lower $D^{*}$ & Lower $D$ & Lower $D^{*}, D$ & Higher $Z^{*}$ & $\begin{array}{c}\text { Higher } Z^{*} \\
\text { Lower } D^{*}, D\end{array}$ \\
\hline Foreign Exporter Trade Cost $\left(D^{*}\right)$ & -5 & 0 & -5 & 0 & -5 \\
Home Exporter Trade Cost $(D)$ & 0 & -5 & -5 & 0 & -5 \\
Foreign Productivity $\left(Z^{*}\right)$ & 0 & 0 & 0 & 35 & 35 \\
Home Import Share & 0.7 & 0.2 & 0.9 & 3.3 & 4.0 \\
Home Firm Markup at Home $\left(\mu_{d}\right)$ & -0.3 & -0.1 & -0.3 & -1.4 & -1.7 \\
a. Home Import Price $\left(p_{m}\right)$ & -1.6 & -0.3 & -1.9 & -8.2 & -9.9 \\
$\quad(a=b+c)$ & 1.8 & 0.3 & 2.2 & 10.9 & 13.9 \\
b. Foreign Exporter's Markup $\left(\mu_{m}\right)$ & -3.5 & -0.7 & -4.1 & -19.1 & -23.8 \\
c. Foreign Marginal Cost $\left(q D^{*} \frac{w^{*}}{Z^{*}}\right)$ & 1.1 & -1.1 & 0 & -17.5 & -17.7 \\
Real Exchange Rate $(q)$ & -1.8 & -0.4 & -2.2 & -9.5 & -11.6 \\
Direct Pass-Through $\left(\kappa_{m}\right)$ & -2.3 & -0.6 & -2.9 & -12.5 & -14.7 \\
Pass-Through $\left(\beta_{p_{m}, q}\right)$ & & & & \\
\hline
\end{tabular}

${ }^{a}$ Entry refers to the log-difference for a variable from its value in the benchmark calibration. For the trade costs, home trade share, $\kappa_{m}$, and $\beta_{p_{m}, q}$, we report the percentage point difference. For $Z^{*}$, we report the arithmetic percentage change instead of the log-difference.

${ }^{b}$ Row a equals row b plus row c with any discrepancy due to rounding. 
Table 5: The Effect of Permanently Lower Trade Costs and Higher Foreign Productivity

\begin{tabular}{|l|c|c|c|}
\hline \multicolumn{1}{|c|}{ for Alternative Model Versions } \\
\multicolumn{1}{|c|}{} & $\begin{array}{c}\text { Without } \\
\text { Entry }\end{array}$ & $\begin{array}{c}\text { With Only Foreign } \\
\text { Exporter Entry }\end{array}$ & $\begin{array}{c}\text { With } \\
\text { Entry }\end{array}$ \\
\hline Foreign Exporter Trade Cost $\left(D^{*}\right)$ & -5 & -5 & -5 \\
Home Exporter Trade Cost $(D)$ & -5 & -5 & -5 \\
Foreign Productivity $\left(Z^{*}\right)$ & 35 & 35 & 35 \\
Home Import Share & 0.7 & 4.6 & 4.0 \\
Home Firm Markup at Home $\left(\mu_{d}\right)$ & -1.7 & -1.9 & -1.7 \\
a. Home Import Price $\left(p_{m}\right)$ & -12.9 & -11.0 & -9.9 \\
$\quad$ (a = b+c) & & & 13.9 \\
b. Foreign Exporter's Markup $\left(\mu_{m}\right)$ & 19.8 & 16.1 & -17.7 \\
c. Foreign Marginal Cost $\left(q D^{*} \frac{w^{*}}{Z^{*}}\right)$ & -23.7 & -19.2 & -11.6 \\
Real Exchange Rate $(q)$ & -15.2 & -13.0 & -11.6 \\
Direct Pass-Through $\left(\kappa_{m}\right)$ & -15.2 & -13.0 & -14.7 \\
Pass-Through $\left(\beta_{p_{m}, q}\right)$ & -15.1 & -13.4 & \\
\hline
\end{tabular}

${ }^{a}$ Entry refers to the log-difference for a variable from its value in the benchmark calibration. For the trade costs, home trade share, $\kappa_{m}$, and $\beta_{p_{m}, q}$, we report the percentage point difference. For $Z^{*}$, we report the arithmetic percentage change instead of the log-difference.

${ }^{b}$ Row a equals row b plus row c with any discrepancy due to rounding. 
Figure 1: The Real Exchange Rate and Relative Import Prices

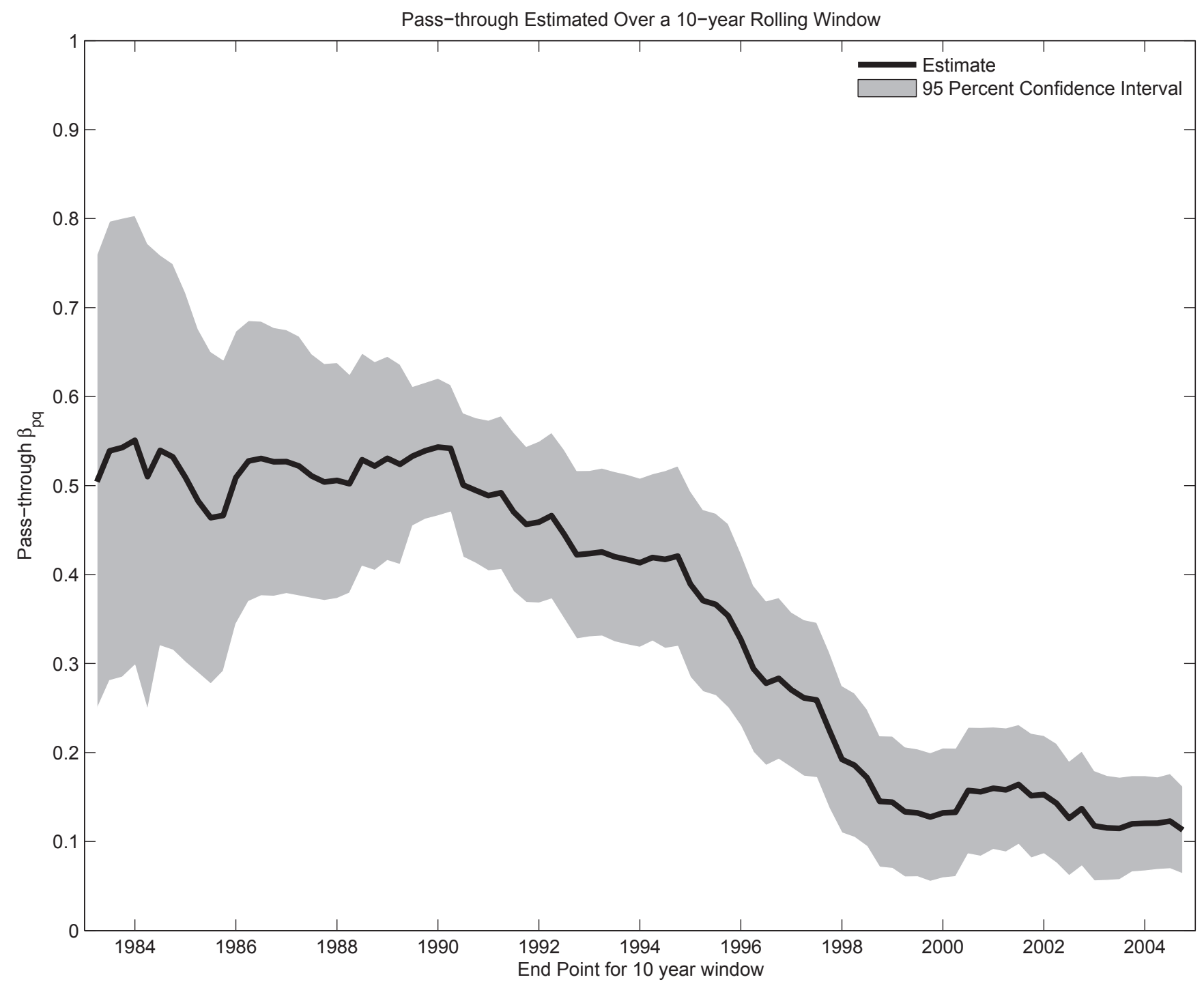


Figure 2: The Decline in Average Transport Costs and Tariffs for U.S. Imported Goods

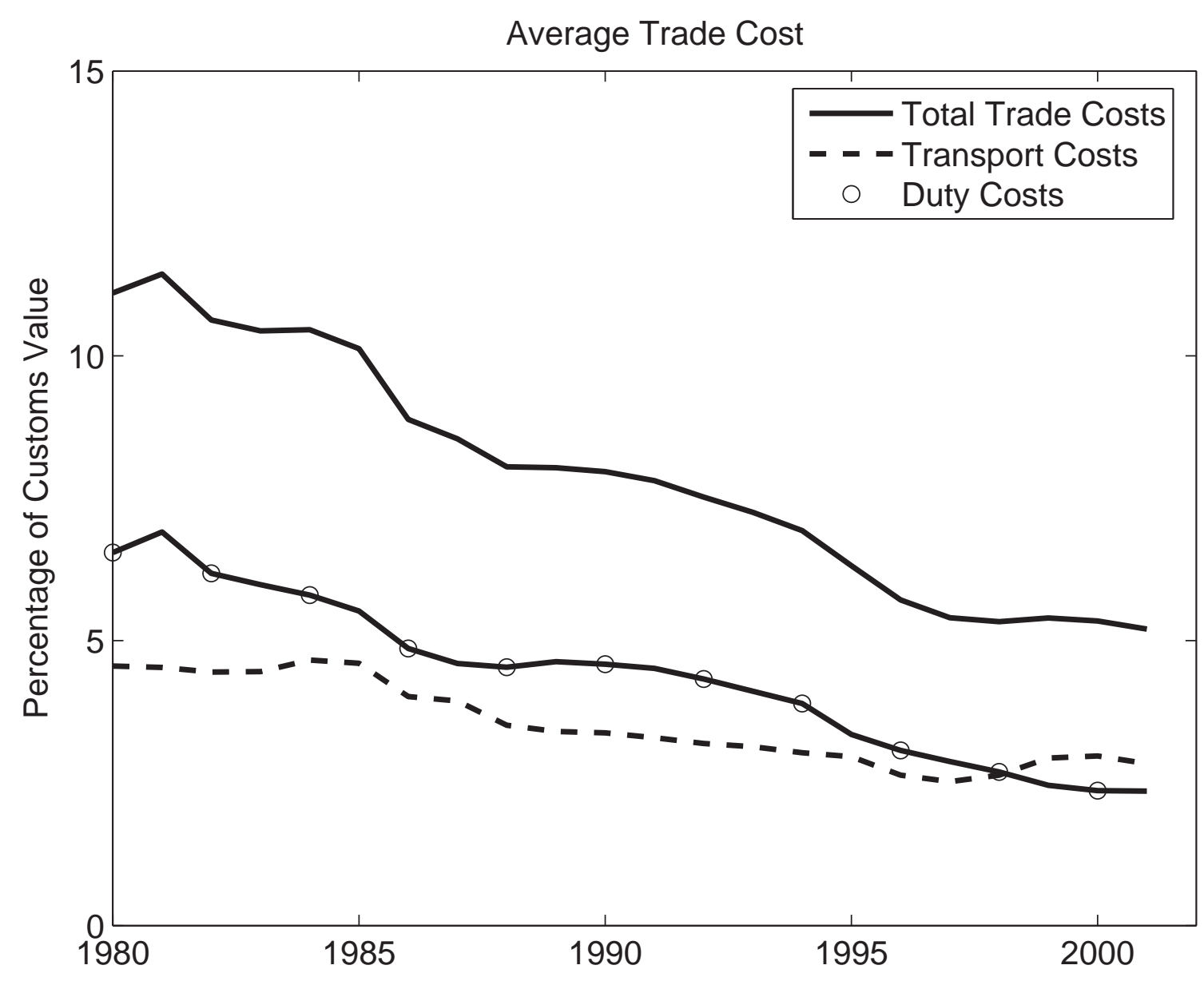


Figure 3: Growth in GDP per Employee in the United States and the Rest of the World
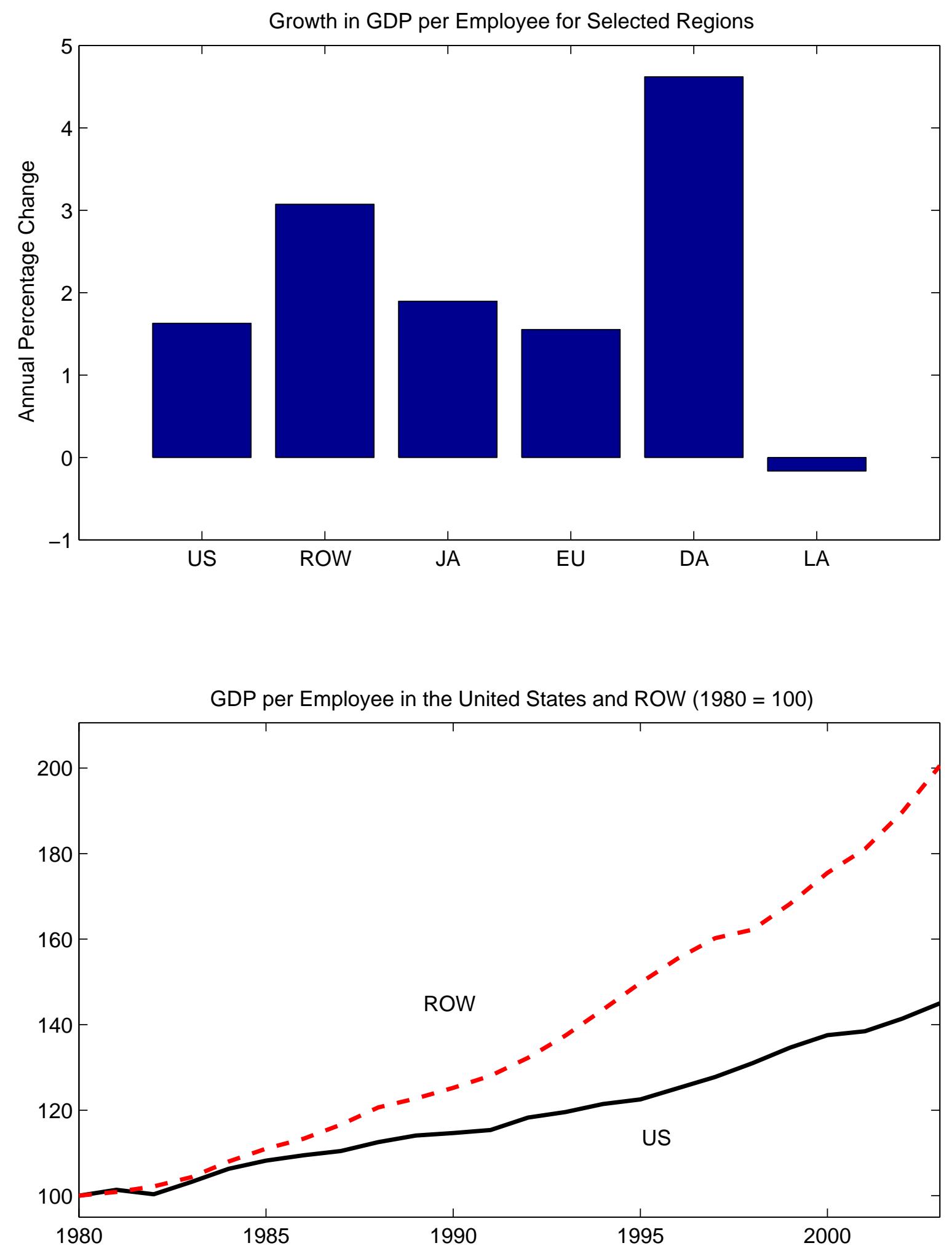
Figure 4: The Effect of the Intensive and Extensive Entry Margins on Pass-Through
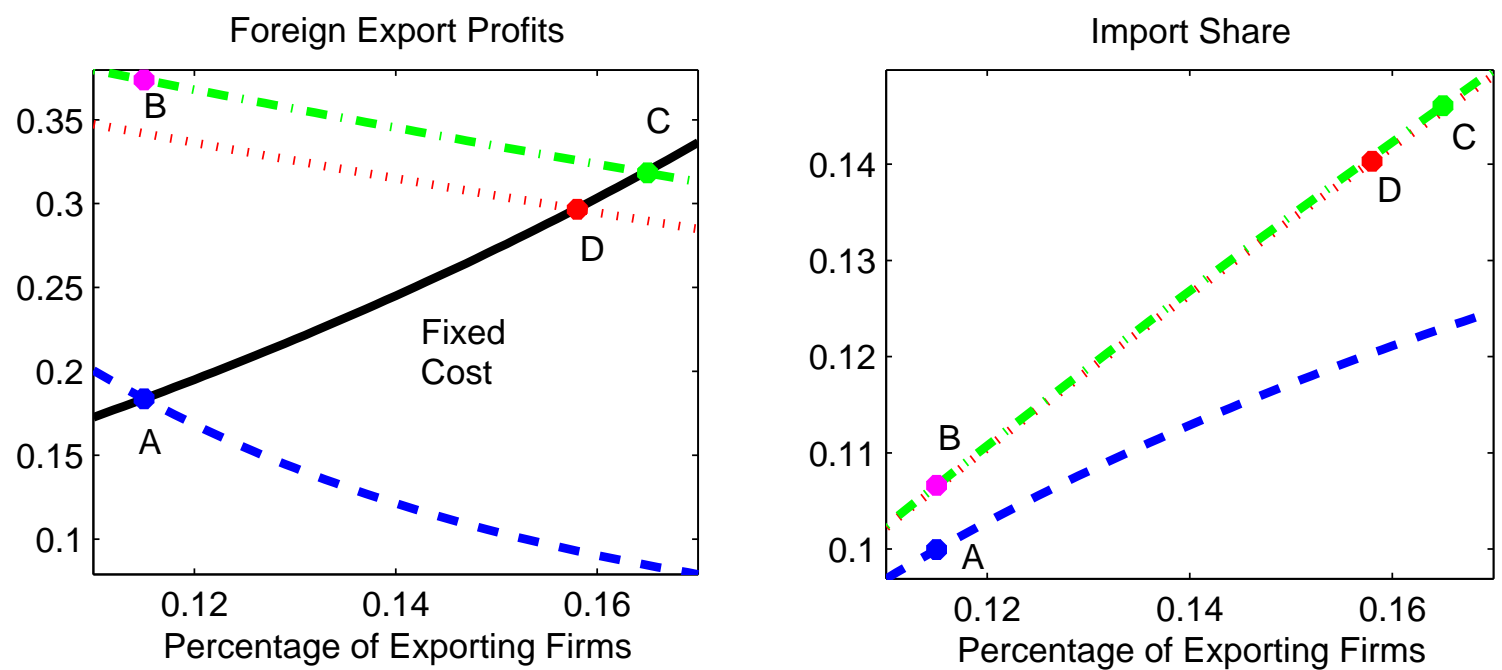

Foreign Exporter Markup
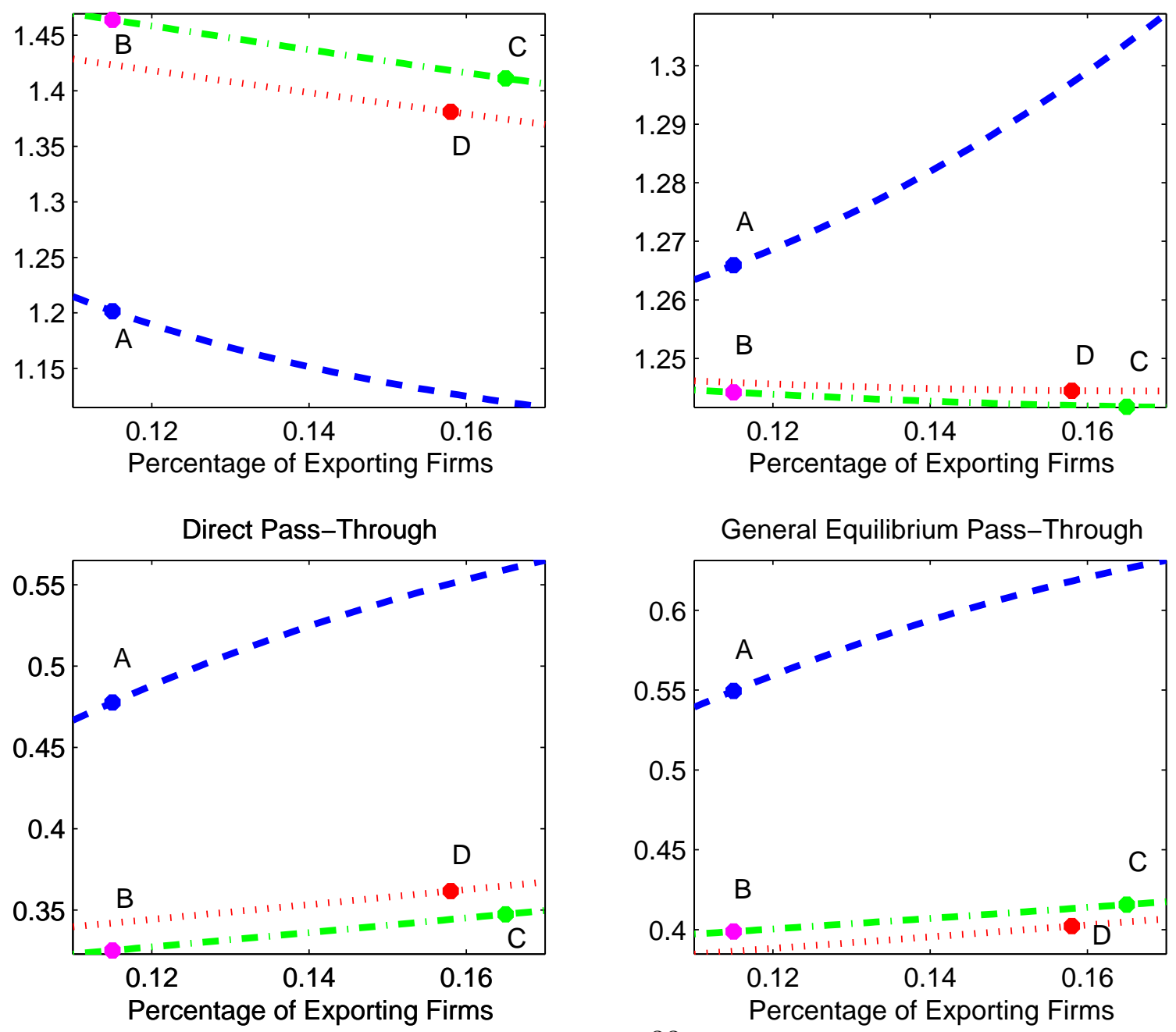

- a Initial Values 33

, $1, \ldots$, New Values

, New Values (Only Foreign Exporter Entry) 